hormone dependent target tissues. In the embryonal tumours, where treatment is having most success, most of the population is maintained in the proliferative cycle and the bulk of cell production is wasted by cell death; Bagshawe ${ }^{5}$ has indicated that these may be cardinal features of cancers that respond to chemotherapy. Now the problem is to think of ways of forcing natural wastage to even higher levels-a strategy that would exploit the innate behaviour of the cancer cells. Conversely, these findings reinforce fears that the large proportion of quiescent cells in many adenocarcinomas puts them beyond the reach of current treatment, though their progress may be impeded by attacking the vulnerable parts of their population.

Given an initial tumour mass of $10 \mathrm{~g}$ and $99 \%$ of cells killed by treatment, $100 \mathrm{~m}$ cancer cells will still be left behind. Only when the effect is expressed in logarithmic terms is one sharply reminded that a reduction from $10^{10}$ to $10^{8}$ cells still leaves a long way to go before the tumour is eradicated.

${ }^{1}$ Malaise, E P, Chavandra, N, and Tubiana, N, European fournal of Cancer, 1973, 9, 305.

2 Tubiana, M, and Malaise, E P, in Scientific Foundations of Oncology, ed T S Symington. London, Heinemann, 1976.

${ }^{3}$ Steel, G G, in Cancer Medicine, eds J F Holland and E Frei, p 125. Philadelphia, Lea and Febiger, 1973.

${ }^{4}$ Cooper, E H, et al, Advances in Cancer Research, 1975, 21, 59.

5 Bagshawe, K D, British fournal of Cancer, 1968, 22, 698.

\section{Social trends}

In the early 1960s a new intellectual fashion was launched in the United States: the social indicators movement. The idea was to complement economic statistics, which record only those changes which are measurable in money terms, with social statistics, which would record changes in the quality of life. Furthermore, these social indicators were seen as serving policy makers in much the same way as economic indicators-as signals for action. In the event, social indicators have turned out to be rather a social scientist's Concorde: prestigious rather than generally useful. However, the movement did generate in Britain one byproduct which has earned its keep-Social Trends, the Central Statistical Office's annual compendium of figures about the state of the nation's health, housing, education, and general welfare (as indicated by such a variety of measures as, for example, crime rates, the breakdown of marriages, and amount of leisure time). Now in its sixth year, ${ }^{1}$ Social Trends has developed into the best available guide to British official statistics, extracting the key figures from the specialist volumes and making them available in a way which allows those interested in, say, health to look at developments in other, possibly relevant, fields.

Apart from its value as a reference book Social Trends should therefore help to discourage people from thinking about health and other social policy issues in compartmental, and that is departmental, terms. Instead, it should stimulate ways of thinking about problems which cross administrative boundaries-for example, discussion of the health needs of the elderly as they relate to housing conditions or the provision of other forms of social support. That sort of approach was indeed recommended by the Government's own "Think Tank" - the Central Policy Review Staff-in a recent report ${ }^{2}$; let us hope its proposals for looking at policy issues within a common framework will not be treated in the same dismissive way as its study of the car industry.
While no one can quarrel with this general approach, it is more difficult to identify the most useful, specific units of analysis. Should it be specific groups such as the elderly ? Should it be geographical groups? Or should it be social groups? Helpfully, the latest issue of Social Trends illustrates some of the practical difficulties by looking at social statistics both by area and by class. In particular it shows that in terms of the distribution of social well-being Britain has a long way to go yet before achieving a classless society, and, as it points out, "The original reason for developing the Registrar General's concept of social class was to examine variations in mortality." Thus semiskilled manual workers tend to suffer more than the other social classes from both chronic and acute sickness, while their children tend to be shorter, with poorer eyesight and more tooth decay, than the rest. Similarly, as social class falls, there is more overcrowding, more unemployment, and less education.

While such statistics may confirm the continuation of inequality on a number of measures, they do not provide any ready answers-and indeed may encourage simplistic, ideologically based policy recipes. For instance, the health of unskilled workers may be poorer than that of the rest of the population for a variety of reasons: because of inherited characteristics, because of working conditions, because of their living environment, or because people in poor health tend to drift down the employment hierarchy into the poorest jobs. It would be dangerous to use the association of poor health (and high use of NHS facilities) with low social class as an argument against the recent recommendations by a DHSS working party ${ }^{3}$ for cutting down the allocation of resources to inner city areas, like London and Liverpool, where at present there is an excess of provision relative to the rest of the country. True, these inner city areas have, as another article in Social Trends shows, a high proportion of unskilled working class families with their associated problems. But it does not follow that these deprived areas require more in the way of medical care as distinct from better housing or other services. So while Social Trends is invaluable as a source of statistics and information it also offers a warning about the amount of work that remains to be done before social statistics become a reliable guide to social action.

1 Central Statistical Office, Social Trends No 6. London, HMSO, 1975. 2 Cabinet Office, Central Policy Review Staff, $A$ foint Framework for Social Policies. London, HMSO, 1975.

3 British Medical fournal, 1975, 4, 66

\section{Computers and privacy}

As more and more agencies and institutions become "computerised" people naturally begin to worry that the data provided will find their way into some amorphous information bank over which they have no control and whose purposes are far removed from those for which the data were originally intended. Most democratic countries and organisations are well aware of the problem. In West Germany and Sweden data protection laws have already been enforced. Draft legislation is under consideration in Norway, Austria, New Zealand, and Canada. The Council of Europe has issued detailed recommendations about the establishment, operation, and development of data banks in both the public and the private sector; comparable views have been expressed in the United States by the Committee on Scientific and Technical 